\title{
MENINGKATKAN HASIL BELAJAR SISWA MELALUI MODEL PEMBELAJARAN KOOPERATIF TIPE JIGSAW DI KELAS IV SDN 4 MALIGANO
}

\author{
Okvianty $^{1)}$, Izlan Sentryo ${ }^{2)}$. \\ 1) SDN 4 Maligano, Muna, Indonesia \\ 2) Jurusan PGSD,Universitas Halu Oleo, Kendari, Indonesia \\ email: izlansentryo@uho.ac.id
}

\begin{abstract}
Abstrak: Penelitian ini adalahPenelitian Tindakan Kelas (PTK) yang terdiri dari tahapan perencanaan, pelaksanaan tindakan siklus, observasi dan evaluasi, dan refleksi. Data yang diperoleh dalam penelitian ini adalah data kuantitatif dan data kualitatif. Data kualitatif diambil dengan menggunakan lembar observasi sedangkan data kuantitatif diambil dari tes hasil belajar. Indikator kinerja dalam penelitian ini meliputi : (1) apabila skenario pembelajaran terlaksana 90\% maka dikatakan berhasil; dan (2) hasil belajar siswa secara klasikal mencapai $80 \%$ dengan nilai KKM 65. Berdasarkan hasil analisis dan pembahasan adalah aktivitas siswa pada siklus I pertemuan ke-1 72,5\%, pada pertemuan ke-2 77,5\% pada siklus II pertemuan ke-1 $85 \%$ dan pertemuan ke-2 90\%, sedangkan aktivitas guru dalam KBM pada siklus I pertemuan ke-1 77,6\%, pertemuan ke-2 $84,2 \%$, pada siklus II pertemuanke-1 $94,7 \%$ pada peertemuan ke-2 mencapai 97,4\% dan hasil belajar siswa pada siklus I mencapai $37,04 \%$ dan pada siklus II meningkat menjadi 85 , $19 \%$.
\end{abstract}

Kata Kunci: Pembelajaran Kooperatif; Tipe Jigsaw; Hasil belajar;

\section{IMPROVING STUDENT LEARNING OUTCOMES THROUGH THE JIGSAW TYPE COOPERATIVE LEARNING MODEL IN CLASS IV SDN 4 MALIGANO}

\begin{abstract}
This research is Classroom Action Research (PTK) which consists of the planning stages, the implementation of the action cycle, observation and evaluation, and reflection. The data obtained in this study are quantitative data and qualitative data. Qualitative data were taken using observation sheets, while quantitative data were taken from learning outcomes tests. Performance indicators in this study include: (1) if the learning scenario is implemented 90\%, it is said to be successful; and (2) classical student learning outcomes reached $80 \%$ with a KKM score of 65. Based on the results of the analysis and discussion, student activity in the first cycle of the first meeting was $72.5 \%$, at the second meeting $77.5 \%$ in the second cycle of the meeting. $85 \%$ and the second meeting $90 \%$, while the activities of teachers in teaching and learning activities in the first cycle of the first meeting were $77.6 \%$, the second meeting was $84.2 \%$, in the second cycle the first meeting was $94.7 \%$ at the second meeting reached $97.4 \%$ and student learning outcomes in the first cycle reached $37.04 \%$ and in the second cycle increased to 85 , $19 \%$.
\end{abstract}

Keywords: Cooperative Learning; Jigsaw Type; Learning outcomes; 


\section{Pendahuluan}

Rendahnya hasil belajar siswa dikarenakan guru dalam menerangkan materi matematika kurang jelas dan kurang menarik perhatian siswa dan pada umumnya guru terlalu cepat dalam menerangkan materi pelajaran. Di samping itu penggunaan metode pengajaran yang salah. Sehingga siswa dalam memahami dan menguasai materi masih kurang dan nilai yang diperoleh siswa cenderung rendah. Berdasarkan pengalaman dan refleksi di kelas kelemahan belajar matematika di kelas IV SD Negeri 4 Maligano adalah bahwa selama proses pembelajaran, guru belum memberdayakan potensi siswa sehingga sebagian besar belum mampu mencapai kompetensi individual yang diharapkan dalam kurikulum. Beberapa siswa belum belajar pada tingkat pemahaman. Siswa baru mampu menghafal fakta, konsep-konsep, hukum teori dan gagasan pada tingkat ingatan. Mereka belum dapat menggunakan dan menerapkannya dalam memecahkan masalah-masalah sehari-hari.

Masalah-masalah di atas merupakan masalah-masalah pendekatan pembelajaran, belum lagi masalah-masalah dari siswa itu sendiri. Terutama pada pelajaran matematika, mengingat pelajaran matematika merupakan mata pelajaran yang terkenal sulit dan memerlukan logika berpikir yang tinggi, selain itu juga dikhawatirkan aktivitas belajar matematika terganggu, jika suasana pembelajaran matematika tidak menyenangkan.

Upaya membangkitkan minat dan meningkatkan hasil belajar siswa kelas IV SD Negeri 4 Maligano dalam pembelajaran matematika sudah dilakukan guru di kelas dengan berbagai strategi, seperti memberi kesempatan kepada siswa untuk bertanya dan mengungkapkan gagasan, serta mendesain pembelajaran dalam bentuk demonstrasi. Dengan hasil rata-rata ulangan harian mata pelajaran matematika khususnya materi KPK dan FPB tahun pelajaran 2014/2015 pada materi pokok KPK dan FPB adalah 55 dimana KKM yang ditetapkan sekolah yaitu 60, pada tahun pelajaran 2015/1016 pada materi pokok KPK dan FPB adalah 58 dimana KKM sekolah mata pelajaran matematika yaitu 62 dan pada tahun pelajaran 2016/2012 pada materi pokok KPK dan FPB belum memuaskan. Rata-rata nilai ulangan harian matematika dari 27 siswa belum mencapai ketuntasan. Dimana Kriteria Ketuntasan Minimal (KKM) mata pelajaran matematika SD Negeri 4 Maligano adalah 65.

Model pembelajaran kooperatif tipe jigsaw merupakan salah satu model mengajar yang dapat diterapkan oleh guru di SD Negeri 4 Maligano untuk mengatasi masalah dalam proses belajar mengajar. Melalui model ini siswa dalam mempelajari materi pelajaran yang dimodelkan atau dipersentasikan lebih dahulu oleh guru secara tahap demi tahap dan terstruktur mulai dari materi yang sifatnya sederhana menuju ke materi yang sifatnya lebih kompleks. Agar setiap siswa dapat menyelesaikan masalah pada konsep yang kompleks maka diberikan pelatihan lanjutan namun masih berada dibawah bimbingan guru.

Slavin (2008: 237) menyatakan bahwa "Pembelajaran kooperatif Jigsaw menjadikan siswa termotivasi untuk belajar karena skor-skor yang dikontribusikan siswa kepada tim didasarkan pada sistem skor perkembangan individual, dan siswa yang skor timnya meraih skor tertinggi akan menerima sertifikat atau bentuk-bentuk rekognisi tim yang lain sehingga siswa termotivasi untuk mempelajari materi dengan baik dan untuk bekerja keras serta aktif dalam kelompok ahli supaya dapat membantu tim melakukan tugas dengan baik". Tiap individu memberi kontribusi pada pencapaian tujuan anggota yang lain pada pembelajaran kooperatif tipe Jigsaw. Tiap anggota kelompok bisa meraih tujuan pribadi jika kelompok sukses sehingga untuk meraih tujuan pribadinya, anggota kelompok harus membantu teman satu tim untuk melakukan apapun guna membuat kelompok berhasil, dan yang lebih penting adalah mendorong anggota satu kelompok untuk melakukan usaha maksimal. Setiap anggota kelompok memotivasi anggota kelompok lain. Johnson \& Johnson (Astuti \& Abadi, 2015) mengungkapkan prestasi akan meningkat ketika situasi pembelajaran dikondisikan dalam bentuk kelompok dibanding jika hanya bersifat persaingan atau individualis. Selama pembelajaran kooperatif 
terjadi pening-katan kompetensi dalam berpikir kritis, lebih bersikap positif terhadap subjek yang dipelajari, peningkatan kompetensi dalam bekerja sama dengan orang lain, peningkatan kesehatan fisik, dan menguatkan persepsi terhadap kejujuran.

Penelitian yang dilakukan Basuki (2015) penggunaan model pembelajaran kooperatif tipe Jigsaw dalam pembelajaran matematika dapat meningatkan aktivitas belajar dan hasil belajar siswa kelas VII SMPN 2 Bumiratu Nuban.

Berdasarkan uraian di atas terkait masih rendahnya hasil belajar matematika siswa kelas IV SD Negeri 4 Maligano maka penulis berupaya ingin menerapkan model pembelajaran kooperatif tipe jigsaw dengan judul "Meningkatkan Hasil Belajar Siswa pada Materi Pokok KPK dan FPB Melalui Model Pembelajaran Kooperatif Tipe Jigsaw di Kelas IV SD Negeri 4 Maligano". Dengan menggunakan model pembelajaran ini diasumsikan dapat meningkatkan hasil belajar siswa kelas IV SD Negeri 4 Maligano pada materi pokok KPK dan FPB.

Masalah dalam penelitian ini adalah: Apakah hasil belajar siswa pada materi pokok KPK dan FPB di kelas IV SD Negeri 4 Maligano dapat ditingkatkan melalui model pembelajaran kooperatif tipe jigsaw? Tujuan penelitian ini adalah untuk meningkatkan hasil belajar siswa pada materi pokok KPK dan FPB di kelas IV SD Negeri 4 Maligano melalui model pembelajaran kooperatif tipe jigsaw. Penelitian ini diharapkan dapat memberikan manfaat bagi guru, siswa, sekolah dan penelitian lainnya.

\section{Metode}

Jenis penelitian adalah penelitian tindakan kelas (PTK). Penelitian ini telah dilaksanakan pada semester I (ganjil) tahun pelajaran 2016/2017 di SD Negeri 4 Maligano dua siklus dengan subyek dalam penelitian ini adalah siswa kelas IV SD Negeri 4 Maligano, yang siswanya berjumlah 27 orang. Penelitian tindakan kelas ini dilaksanakan dalam dua siklus yang terdiri dari empat tahapan yaitu perencanaan, pelaksanaan tindakan, observasi dan evaluasi serta refleksi Jenis data dalam penelitian ini adalah data kualitatif dan kuantitatif. Data kualitatif berupa kegiatan proses pembelajaran aktivitas belajar siswa dan aktivitas guru. Data kuantitatif berupa nilai hasil belajar siswa. Sumber data dalam penelitian ini adalah guru dan siswa Kelas IV SD Negeri 4 Maligano Kabupaten Muna.

Data kualitatif akan dianalisis secara deskriptif kualitatif berdasarkan observasi, sedangkan data kuantitatif dianalisis secara kuantitatif menggunakan rumus:

1. Data Hasil Observasi Aktivitas Pembelajaran (aktivitas siswa dan guru) dan jurnal refleksi dianalisis dengan menggunakan rumus:

$\%$ Keterlaksanaan $=\frac{\text { Skorperolehan }}{\text { skorideal }} \times 100 \%$

(Nasution. 2003:29)

2. Data hasil belajar siswa dianalisis dengan menggunakan rumus:

Rata-rata $=\frac{\text { JawabanBenar jumlah nilai yang diperoleh siswa }}{\text { jumlah seluruh siswaTotalskor }} \times 100 \quad$ (Rakhmat,2003:153)

3. Menentukan persentase ketuntasan belajar secara klasikal menggunakan rumus:

$$
\text { \% TuntasKlasikal }=\frac{\sum T B I}{N} x 100 \quad \text { (Nasution, 2008: 6.11) }
$$

Indikator dalam penelitian ini adalah dilihat dari dua segi yaitu segi proses dan segi hasil. Dari proses dikatakan berhasil apabila minimal $90 \%$ skenario pembelajaran terlaksana dengan baik, sedangkan dari segi hasil belajar minimal $80 \%$ siswa memperoleh nilai $\geq 65$ (sesuai dengan KKM sekolah) 


\section{Hasil}

\section{Hasil Belajar Siswa}

Hasil evaluasi tes yang dilakukan pada siklus I pertemuan ke-2 menunjukkan bahwa pemahaman siswa terhadap materi tentang KPK dan FPB adanya peningkatan bila dibandingkan dengan hasil evaluasi pada siklus I pertemuan ke-1. Terdapat sekitar 37,04\% atau sebanyak 10 siswa telah menguasai materi pada siklus I dan mengalami peningkatan jika dibandingkan dengan hasil ulangan harian tahun lalu yaitu 26,67\% atau sebanyak 8 siswa yang memahami tentang materi ini. Walapun terjadi peningkatan, namun peningkatan tersebut belum mencapai KKM yang telah ditentukan sekolah yaitu 65

Dari soal-soal evaluasi tersebut, maka pada pelaksanaan tindakan siklus II ini hasil belajar siswa menunjukkan bahwa terdapat $85,19 \%$ siswa telah menguasai materi yang telah diajarkan, ini berarti memperlihatkan terjadi peningkatan $48,15 \%$ dari pelaksanaan tindakan siklus I.

\section{Aktivitas Guru}

Hasil analisis pengamatan aktivitas guru selama pembelajaran berlangsung pada siklus I pertemuan ke-1 dengan skor maksimal 76, skor perolehan 59, persentase keterlaksanaan RPP adalah 77,6\% diolah dari skor perolehan dibagi skor maksimal dikali dengan $100 \%$ sehingga mendapatkan $77,6 \%$ dan pada siklus I pertemuan ke-2 skor maksimal 76 skor perolehan 64, persentase keterlaksanaan RPP 84,2\%.

Hasil analisis pengamatan aktivitas guru selama pembelajaran berlangsung pada siklus II pertemuan ke-1 dengan skor maksimal 76, skor perolehan 72, persentase keterlaksanaan RPP adalah 94,7\% diolah dari skor perolehan dibagi skor maksimal dikali dengan $100 \%$ sehingga mendapatkan $94,7 \%$ dan pada siklus II pertemuan ke-2 skor maksimal 76 skor perolehan 74, persentase keterlaksanaan RPP 97,4\%.

\section{Aktivitas Siswa}

Hasil analisis pengamatan aktivitas belajar siswa pada siklus I pertemuan ke-1 dengan skor maksimal 40 dan skor perolehan 29 maka persentanse aktivitas siswa pada siklus I pertemuan ke-1 ini adalah skor perolehan dibagi skor maksimal dikali dengan $100 \%$, jadi persentase aktivitas belajar siswa adalah $72,5 \%$. Dan pada siklus I pertemuan ke-2 dengan skor maksimal 40, skor perolehan 31, persentase aktivitas belajar siswa $77,5 \%$ diolah dari skor perolehan bagi skor maksimal dikali $100 \%$

Hasil analisis pengamatan aktivitas belajar siswa pada siklus II pertemuan ke-1 dengan skor maksimal 40 dan skor perolehan 31 maka persentanse aktivitas siswa pada siklus II pertemuan ke-1 ini adalah skor perolehan dibagi skor maksimal dikali dengan 100\%, jadi persentase aktivitas belajar siswa adalah $85 \%$. Dan pada siklus II pertemuan ke-2 dengan skor maksimal 40, skor perolehan 36, persentase aktivitas belajar siswa $90 \%$ diolah dari skor perolehan bagi skor maksimal dikali $100 \%$.

\section{Pembahasan}

Berdasarkan hasil analisis data terhadap aktivitas guru pada siklus I menunjukkan bahwa aktivitas guru dalam proses pembelajaran sudah cukup baik, dimana guru dianggap sudah bisa melaksanakan kegiatan belajar mengajar sesuai dengan skenario pembelajaran, walaupun masih ada beberapa kekurangan dalam pelaksanaannya, seperti keterampilan guru untuk mengkoordinasi siswa ke dalam kelompok heterogen masih kurang baik dan menyimpulkan tujuan pembelajaran serta antusias siswa masih kurang baik. Beberapa kekurangan ini terjadi karena guru masih kaku dalam menggunakan model pembelajaran kooperatif tipe Jigsaw. 
Beberapa kekurangan pada siklus I kemudian direfleksi dan dilakukan perbaikanperbaikan untuk pelaksanaan tindakan pada siklus II. Hasil refleksi tersebut menjadi pedoman dalam pelaksanaan siklus II.

Pada pelaksanaan tindakan siklus II terlihat kemajuan, hal ini dapat dilihat dari hasil analisis data terhadap aktivitas belajar siswa pada siklus II pertemuan ke-1 yaitu $72,5 \%$ pada pertemuan ke-2 yaitu 77,5\% dan pada siklus II pertemuan ke-1 yaitu $85 \%$ dan ke-2 yaitu $90 \%$. Ini berarti bahwa aktivitas belajar siswa dari siklus I meningkat sangat baik berdasarkan kriteria keterlaksanaan walaupun masih ada yang kurang terutama dalam menghargai/menerima pendapat dimana siswa masih menganggap remeh jawaban temannya, meskipun demikian siswa sudah memahami model pembelajaran yang diterapkan.

Hal ini sejalan dengan pendapat Darsono (2000: 24), menyatakan bahwa " Model pembelajaran kooperatif tipe Jigsaw adalah pembelajaran dimana siswa belajar dalam kelompok bertanggungjawab atas penguasaan materi belajar yang ditugaskan kepadanya lalu mengajarkan bagian tersebut pada anggota kelompok lain". Jadi pembelajaran tipe Jigsaw ini merupakan bagian dari pembelajaran kooperatif yang merupakan pembelajaran kelompok dimana setiap anggota bertanggungjawab atas penguasaan materi tertentu dan mengajarkannya kepada anggota kelompoknya setelah mempelajari dengan kelompok ahli masing-masing.

Para anggota dari kelompok asal yang berbeda, bertemu dengan topik yang sama dalam kelompok ahli untuk berdiskusi dan membahas materi yang ditugaskan pada masingmasing anggota kelompok serta membantu satu sama lain untuk mempelajari topik mereka tersebut. Disini, peran guru adalah memfasilitasi dan memotivasi para anggota kelompok ahli agar mudah untuk memahami materi yang diberikan. Setelah pembahasan selesai, para anggota kelompok kemudian kembali pada kelompok asal dan mengajarkan pada teman sekelompoknya apa yang telah mereka dapatkan pada saat pertemuan di kelompok ahli. Para kelompok ahli harus mampu untuk membagi pengetahuan yang didapatkan saat melakukan diskusi di kelompok ahli, sehingga pengetahuan tersebut diterima oleh setiap anggota pada kelompok asal. Kunci tipe Jigsaw ini adalah setiap siswa bertanggung jawab terhadap anggota tim yang memberikan informasi yang diperlukan. Artinya para siswa harus memiliki tanggungjawab dan kerja sama yang positif dan saling ketergantungan untuk mendapatkan informasi dan memecahkan masalah yang diberikan.

Model pembelajaran kooperatif tipe Jigsaw adalah salah satu model pembelajaran yang didesain untuk meningkatkan rasa tanggungjawab siswa terhadap pembelajaranya sendiri dan juga pembelajaran orang lain. Siswa tidak hanya mempelajari materi yang diberikan, tetapi mereka juga harus siap memberikan materi tersebut kepada kelompoknya. Sehingga baik kemampuan secara kognitif maupun sosial siswa sangat dibutuhkannya

\section{Simpulan}

Berdasarkan hasil analisis dan pembahasan pada bab sebelumnya disimpulkan bahwa hasil belajar siswa pada materi pokok KPK dan FPB melalui model pembelajaran kooperatif Tipe Jigsaw di SD Negeri 4 Malogano dapat ditingkatkan. Hal ini dapat dilihat pada peningkatan hasil belajar siswa pada siklus 1 yaitu 37,04 \% dan pada siklus 2 meningkat menjadi $85,19 \%$. 


\section{Referensi}

Astuti, R.D., \& Abadi, A.M. (2015). Keefektifan Pemeblajaran Jigsaw dan TAI Ditinjau dari Kemampuan Penalaran dan Sikap Belajar Matematika Siswa. Jurnal Riset Pendidikan Matematika Vol. 2 Nomor 2. https://journal.uny.ac.id/index.php/jrpm/article/view/7339/6322.

Basuki, N. (2015). Peningkatan Aktivitas dan Hasil Belajar Siswa Menggunakan Model Pembelajaran Kooperatif Tipe Jigsaw Pada Mata Pelajaran Matematika Siswa Kelas VII SMPN 2 Bumiratu Nuban Tahun Pelajaran 2014/2015. Jurnal Pendidikan Matematika FKIP Univ. Muhammadiyah Metro Vol. 4 No. 1. http://ojs.fkip.ummetro.ac.id/index.php/matematika/article/download/96/82.

Darsono. 2000. Belajar dan pembelajaran. Semarang : IKIP Semarang Press.

Nasution. (2003). Metode Penelitian Naturalistik Kualitatif. Bandung: Transito

Nasution. (2008). Berbagai Pendekatan dalam Proses Belajar \& Mengajar. Cetakan Kedua Belas. Jakarta: Bui Aksara.

Rakhmat, J. (2003). Metode Penelitian Komunikasi. Bandung: PT. Remaja Rosdakarya.

Slavin, Robert E. 2008. Cooperative Learning. Bandung: Nusa Media. 